\title{
Empowered by stigma? Pioneer organic farmers' stigma management strategies
}

\author{
Merja Lähdesmäki ${ }^{\mathrm{a}, *}$, Marjo Siltaoja ${ }^{\mathrm{b}}$, Harri Luomala ${ }^{\mathrm{c}}$, Petteri Puska ${ }^{\mathrm{c}}$, Sami Kurki ${ }^{\mathrm{a}}$ \\ ${ }^{a}$ University of Helsinki, Ruralia Institute, Kampusranta 9 C, 60320, Seinäjoki, Finland

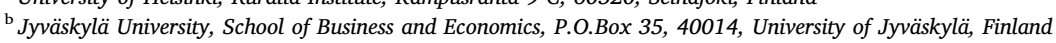 \\ ${ }^{\mathrm{c}}$ University of Vaasa, Faculty of Business Studies, Wolffintie 34, 65200, Vaasa, Finland
}

\section{A R T I C L E I N F O}

\section{Keywords:}

Organic farmer

Stigmatization

Stigma management

Finland

\begin{abstract}
A B S T R A C T
Pioneers of organic farming often faced social challenges as their innovative ideas on agriculture not only encountered opposition in the conventional farming community, but led to stigmatization of organic farmers as social deviants. In this study, we examine what kind of stigma management strategies pioneer organic farmers engage with in order to cultivate an alternative positive image of themselves. Our research is based on the interviews with 14 pioneer organic farmers. Based on a qualitative analysis of the interviews, we provide a model of those strategies that the creation from a stigmatized to valued identity requires. Our study increases the understanding of the institutionalization process of organic farming by demonstrating how pioneer organic farmers overcame the negative attributes associated with their farmer identities while actively building a new agricultural category which was different from that of conventional farming.
\end{abstract}

\section{Introduction}

Organic farming refers to a land-use system which has the potential to address many current societal needs, thus emerging as a critique of materialistic and mechanistic agriculture based on chemistry (Stinner, 2007). Organic farming started to develop in the early 20th century through various different ideas which all aimed at creating a sustainable agricultural production system (Padel, 2001). The growth of organic farming was not just a matter of adopting particular cultivation methods; rather it represented an introduction of specific societal, environmental and economic goals into agriculture at large (Crowder and Reganold, 2015; Michelsen, 2001). Therefore, organic agriculture signalled multidimensional processes of change - including the changes in institutional levels of society as the supposed merits of organic farming did not always conform to conventional agricultural criteria (e.g. Ingram, 2015; Michelsen, 2001; Tovey, 1999). For this reason, the pioneers of organic farming often faced social challenges as their innovative ideas on agriculture not only encountered opposition in the conventional farming community, but led stigmatization of organic farmers as social deviants. For example, based on the previous literature, Sutherland (2013, p.430) states that there was a social stigma related with the pioneers of organic farming as "the initial converts were ostracized from farming circles" (see also Padel, 2001; Smith,
2006).

According to Goffman's (1963, p.3) well acknowledged definition, stigma is "an attribute that is deeply discrediting" and that reduces the bearer "from a whole and usual person to a tainted, discounted one". Stigmatization is one of the strongest means to label someone or something as carrying a tainted or spoiled identity (Hudson, 2008). It appears as a power process which results in negative judgments based on an offending attribute that is regarded as a deviant one, thus aiming to marginalize an individual from full societal acceptance (e.g. Crocker et al., 1998; Miller and Kaiser, 2001; Toyoki and Brown, 2014). While the previous literature on organic farming acknowledges the existence of stigma (e.g. Duram, 2010; Lockeretz, 2007; McGreevy, 2012; Padel, 2001; Smith, 2006: Stock, 2007; Strochlic and Sierra, 2007; Sutherland, 2013; Tovey, 1997; Wheeler, 2008), the process through which pioneer organic farmers were able to manage the stigma has not been addressed in a systematic way.

Our study is motivated by the following research question: what kind of stigma management strategies did pioneer organic farmers engage with in order to cultivate an alternative positive image of themselves? We focus on Finnish pioneer organic farmers who started their farming careers in the 1970s or 1980s. In 1970, there were officially fewer than 20 organic farms whereas there were over 250000 conventional farms (Luomuliitto, 2005). Currently there are over 4600

\footnotetext{
* Corresponding author.

E-mail addresses: merja.lahdesmaki@helsinki.fi (M. Lähdesmäki), marjo.siltaoja@jyu.fi (M. Siltaoja), harri.luomala@uwasa.fi (H. Luomala), ppuska@uwasa.fi (P. Puska), sami.p.kurki@helsinki.fi (S. Kurki).
} 
organic farms in Finland (including those being in the middle of the transition process) and together they comprise 11.4 per cent of all the cultivated land area (Evira, 2017). This development reflects the more general agricultural trend in the European Union where organic area has been increasing by about 500000 ha per year (EU, 2015). It can be argued that even though conventional farming is still the dominant farming method in Finland, as well as in other European countries, organic farming has moved from the marginal position to integration by the society (see Kaltoft, 1999). This provides an interesting setting for the examination of stigma management strategies among pioneering organic farmers.

We argue that stigma management, more particularly pioneer organic farmers' ability to resist the stigmatizing conceptions and transform them into socially valued and legitimate identities, has significantly enhanced the social acceptability of organic farming. We provide a model of those strategies the creation from a stigmatized to a valued identity requires. Accordingly, our study increases the understanding of the institutionalization process of organic farming by demonstrating how pioneer organic farmers overcame the negative attributes associated with their farmer identities. More generally, our study contributes to the discussion on sustainable food production by demonstrating how stigmatization can be used as an extreme means of social control in order to sustain existing institutional order.

\section{Setting the scene: The Finnish pioneer organic farmers}

The term 'organic' has gone from marginal towards mainstream in western societies as a whole industry has arisen around organic farming during the past couple of decades. This break-through of organic agriculture can be best described as an institutionalization process in which organic farming was promoted by numerous initiatives originating in different parts of society (Michelsen, 2001). At the local level, actors experimenting with innovative sustainable solutions played an important role in spreading a more sustainable form of agriculture (Ingram, 2015; Källander, 2007; Padel, 2001). In the Finnish context, the pioneer organic farmers in the 1970s and 1980s were among the very first to introduce organic farming to the farming community. They established the national framework for the farming method and started to develop the field through innovation and organization (Yli-Viikari, 2016). The pioneering role of these early adapters is particularly highlighted through the fact that organic farming as a phenomenon originated practically without the support of governments, scientific institutions, extension services or special legislation (Goewie, 2002). Pioneer organic farmers can therefore be characterized as institutional entrepreneurs who introduced and worked for a change in the agricultural practice (Michelsen, 2001; see also Battilana et al., 2009; Maguire et al., 2004; Mutch, 2007).

In Finland, the early exponents of organic farming were often motivated in their aims for the agricultural change by broad environmental concerns (e.g. Rajala, 1995; Yli-Viikari, 2016). The Finnish agriculture during the late 1970s and 1980s could be best characterized by intensifying productivist ideology where emphasis was placed on statesupported expansive agricultural production through intensive farming methods and biochemical applications (e.g. Yli-Viikari, 2016). By giving up the artificial fertilizers and other farming chemicals, the pioneer organic farmers stood up as a group to differentiate from the agricultural zeitgeist (see Stock, 2007). They further aimed to accomplish a change in the institutionalized agricultural practice by developing new norms and patterns of agricultural behaviour consistent with their identities and interests, as well as establish them as legitimate to others (Mononen, 2008). Therefore, from early on, the pioneer organic farmers started to organize around local and regional associations with the aim of promoting awareness of, and enthusiasm for, organic farming in Finland (Mononen, 2008). These new, formal associations gave the pioneers an opportunity to shape how the discourse of 'organic' was understood and put into practice, an opportunity extended when the Finnish Organic Association was established in 1985 (Herman et al., 2018). The mission of this national association was to increase the official status of organic farming among political decision-makers and consumers (Luomuliitto, 2005).

Even though 'organics' was part of the Finnish agricultural discourse since the early 1980 s, organic farming as a potential production method was overlooked in the agricultural policy (Mononen, 2008). The key actors in the Finnish agricultural regime, particularly those operating in administration, research and education, did not perceive organic farming as a noteworthy production method (Yli-Viikari, 2016). A significant change towards organic farming at the national policy level occurred in 1990 when economic support for the organic conversion was granted - at the instigation of the Finnish Organic Association (Luomuliitto, 2005). Mainly due to the financial support made available for conversion, the number of organic farms increased from to 1818 by the year 1994 (Organic Europe, 2012). After becoming a member in the European Union in 1995, the common agri-environmental programs became a cornerstone of the Finnish agricultural policy (Padel and Lampkin, 2007, p.102). The union membership also created a new wave of farms converted to organic farming (Organic Europe, 2012). Today organic farming is a part of the country's official brand strategy, with over 4000 certified organic farms (Evira, 2016). Thus, despite the challenges in gaining legitimacy in the field of farming, pioneer organic farmers succeeded in establishing a solid foothold for organic farming in Finland. In order to leverage resources to transform the existing agricultural institutional arrangements, the pioneer organic farmers needed, however, to overcome the negative, stigmatizing attributes associated with organic farming.

\section{Theoretical framework: managing a stigmatized identity}

The theoretical discussion of stigma is often traced back to Erwin Goffman (1963) who defined stigma as an identity discrediting mark. While Goffman (1963) further categorized stigmas into three types, namely those based on physical deformities, character blemishes and tribal characteristics, the contemporary research emphasizes how stigmas are discursively produced human perceptions (Meisenbach, 2010). More specifically, stigma is perceived as a "social construction that results from the interaction between the target of stigmatization and the audience of perceivers that produce the stigmatization" (Paetzold et al., 2008, p. 186). Given the profoundly social nature of stigma, the "construction and experience of stigma are constituted differently across social contexts and are not permanent but can shift over time through the interactions of discourses" (Toyoki and Brown, 2014, p. 717). Consequently, stigma should be comprehended as inherently dynamic in practice as a stigmatizing attribute in one situation may be neutral or even positive in another (Paetzold et al., 2008).

Stangor and Crandall (2000) argue that stigmatization is triggered by a perceived threat to the individual, like for example, the threat of loss of power and/or social advantage (see also Phelan et al., 2008). In case of pioneer organic farmers, while organic farming was associated with a number of positive environmental, economic and health-related attributes, it was simultaneously imbued, at least implicitly, the challenges or even failures in conventional farming. This built-in criticism represented a threat to conventional farmers' social identities - leading to a need to defend themselves and their farming (e.g. Padel, 2001). Stigmatization can thus be understood as a means, even though an often extreme one, to build group solidarity through a distinction between insiders and outsiders (Falk, 2001). Link and Phelan (2001, p. 367), for example, argue that "stigmatization is entirely contingent on access to social, economic and political power that allows the identification of differentness, the construction of stereotypes, the separation of labelled persons into distinct categories and the full execution of disapproval, rejection, exclusion and discrimination".

Because of their exposure to the dominant culture and ideologies, stigmatized individuals usually develop a shared understanding of the 
prevailing idea of their stigmatized status in the eyes of others (Major and O'Brien, 2005). But even though stigmatized individuals are aware of the collective and stereotypical representations aimed at their devaluation and marginalization, this does not need to lead to the internalization of these judgements (Crocker and Major, 1989). Stigmatization literature thus makes a categorization between public and selfstigma where the former refers to the "negative stereotypes that society places on the stigmatized individual, whereas self-stigma refers to the degree to which individuals internalize these judgments and stereotypes" (Shih, 2004, p.177).

The pioneers introduced their new agricultural ideas during the time when good farmer identity was strongly equated with productivist farming ideas with overwhelmingly utilitarian approach to land use based on intensive forms of agricultural production (Burton, 2004, p. 198). The physical appearance or attractiveness of the crop (animals) were considered as the main visual signs of good farming (Burton, 2004; Sutherland, 2013). Adhering to productivist ideals enabled a farmer to obtain social status and recognition within the community and build ones identity as a good farmer (Burton, 2004). For pioneer organic farmers, the conversion to organic agriculture meant a threat to one's identity as the production of the productivist signs of good farming became challenging and needed to be renegotiate (see Sutherland, 2013). Therefore, in this study, we understand stigma management strategies to comprise an important element in the identity work of stigmatized individuals (see Lutgen-Sandvik, 2008; Toyoki and Brown, 2014) as they provide means for "forming, repairing, maintaining, strengthening or revising the constructions that are productive of a sense of coherence and distinctiveness" (Sveningsson and Alvesson, 2003, p. 1165). Thus, instead of viewing identity as a fixed characteristic, we understand it as a reflexive project of the self which is "maintained when internally perceived as authentic and externally approved by important others" (Lutgen-Sandvik, 2008, p. 99). While in stable conditions, identity work is rather instinctive, people can engage in more aware and focussed identity work when the routinized reproduction of self-identity is discontinued (Alvesson et al., 2008). For pioneer organic farmers, the conversion to organic farming represented an occupational shift which, due to stigmatization, engaged them in renarrating their self-identity to fit within a new set of life circumstances.

As noted above, the stigmatization of pioneer organic farmers was related to their occupational choices and identities. It has been argued that occupational-related stigmas - in comparison with other types of stigmas - are particularly harmful to an individual's identity since occupations often are essential blocks in one's identity construction (Kreiner et al., 2006). Indeed, Ashforth and Kreiner (2007) argue that when understandings of one's occupation is tainted in the minds of others it can severely threaten the sense of one being engaged in an appreciated activity. Accordingly, previous research on stigmas has paid considerable attention to different strategies people use to conceal or manage their stigmatized occupational identities in order to mitigate problematic encounters with normative culture (Nguyen et al., 2014). In organizational research, the literature on dirty work has particularly focused on physically, socially and morally stigmatized occupations and the various strategies occupational members have used to respond these identity threats (e.g. Ashforth and Kreiner, 1999; Ashforth et al., 2007; Van Vuuren et al., 2016). The previous research has demonstrated, for example, how stigmatized individuals or groups are able to develop and manage an alternative conception of themselves by reframing, refocusing and recalibrating occupational ideologies, creating social buffers or engaging in different defensive tactics (Ashforth and Kreiner, 2014).

The occupational stigma management strategies highlighted in previous studies often focus on different tactics that allow individuals to cope with stigma's negative consequences (e.g. Ashforth and Kreiner, 1999; Ashforth et al., 2007). Stigma management strategies are thus defensive and self-directed as they entail the assumption that "stigmatized individuals accept the stigma and find ways to carry on without affecting the mainstream culture" (Nguyen et al., 2014, p.187). However, in this study the pioneer organic farmers are regarded as institutional entrepreneurs who mobilized resources and were actively seeking to create an influence on the contemporary agricultural status quo (e.g. Lawrence et al., 2002; Leca et al., 2008; see also Glezos, 2016). Previous literature has further argued that successful institutional entrepreneurs are those whose subject positions provide them with legitimacy with respect to diverse stakeholders (Maguire et al., 2004). Thus, institutional entrepreneurs need to manage stigma in the manner that makes them valued and legitimate actors in the eyes of stigmatizing audiences. Institutional entrepreneurs' stigma management needs to aim for the transformation of a deviant identity into legitimized, non-deviant one (Warren, 1980). We therefore suggest that through stigma management the pioneer organic farmers, who aimed to change agricultural institutions, should be able to re-narrate their stigmatized identities in a manner that gives others reason to collaborate with them (see Garud et al., 2007).

\section{Data collection and analysis}

This research is based on the interviews with 14 pioneer organic farmers. The farmers were contacted through organic farming associations while the selection of the interviewees was based on a purposeful selection method (Patton, 2002). In other words, all the interviewed organic farmers had engaged in organic agriculture before governmental support for organic farming was launched in 1990. By setting this criterion, we were able to focus on those farmers who were pioneering organic farming methods in Finland, and could be described as institutional entrepreneurs in the context of agriculture. In addition to this criterion, the farms covered a range of different lines of production (see Table 1). The interviewed organic farmers were also geographically dispersed as they were located in six different regions.

While biodynamic farming was the first form of alternative farming introduced in Finland (see Mononen, 2008), the pioneer organic farmers usually applied some ideas of biodynamics in their farming (for example the idea of the farm and farming as an entity in which the human and animal welfare has a central role and production volumes have limits). Biodynamics is also closely related to Rudolf Steiner's principles of anthroposophist philosophy (Kirchmann, 1994). These ideological underpinnings were, however, often regarded as unfamiliar to the farmers' personal values and therefore not internalized in the everyday farming practices. Thus, the majority of the interviewees (12/ 14) did not consider themselves as biodynamic farmers but characterized themselves more generally as organic farmers.

Most of the interviewed farmers were already officially retired at

Table 1

Characteristics of the interviewed pioneer organic farmers.

\begin{tabular}{llll}
\hline $\begin{array}{l}\text { Number of the } \\
\text { interviewee }\end{array}$ & $\begin{array}{l}\text { The year converted } \\
\text { to organic farming }\end{array}$ & $\begin{array}{l}\text { The main } \\
\text { production }\end{array}$ & $\begin{array}{l}\text { Part-time or } \\
\text { full-time } \\
\text { farming }\end{array}$ \\
\hline 1 & 1973 & $\begin{array}{l}\text { Sucklers and } \\
\text { vegetables }\end{array}$ & Full-time \\
2 & 1986 & Arable & Part-time \\
3 & 1980 & Arable & Full-time \\
4 & 1977 & Arable & Full-time \\
5 & 1987 & Arable & Part-time \\
6 & 1989 & Arable & Full-time \\
7 & 1988 & Sucklers and & Full-time \\
chickens (eggs) & Arable & Full-time \\
8 & 1975 & Arable & Part-time \\
9 & 1988 & Arable & Full-time \\
10 & 1984 & Milk production & Full-time \\
11 & 1970 s & Arable & Full-time \\
12 & 1977 & Milk production & Full-time \\
13 & 1970 s & Arable & Full-time \\
14 & 1970 s & & \\
\hline
\end{tabular}


the time of the interviews, while two of them took care of the farm work by themselves. Some of the retirees were still actively involved in the farming, thus helping the successors in everyday activities.

Stock (2007, p.87) has stated that many organic farmers "emphasize their ability to shake up the social order". Similarly, the interviewed pioneer organic farmers in this study can be described as institutional entrepreneurs since while they were initiating changes in their own farming methods, they were actively influencing other (conventional) farmers, (agricultural) policy makers, consumers and scientific actors in order to accomplish changes in the agricultural institution at the time. Like one of the interviewees stated: "It was crystal clear for me that there is something wrong with the Finnish agriculture and I wanted to make it right again. It was my objective" (Int.14). The methods the pioneer organic farmers used to contribute to the agricultural change varied. The most common method mentioned was to take actively part in organic farming associations that were established by the pioneer organic farmers in the early 1980s. The political influence done through the associations was considered very important, like demonstrated by one the interviewees: "I have made the impact to the agricultural change by establishing the organic farming association in our region in the early 1980s. Those taking part in these associations were the ones who provided the settings for other farmers to convert into organic agriculture" (Int 3). Other methods include influencing through different media, lobbying and taking part in political parties (see Table 2).

The semi-structured, in-depth interviews were conducted between May 2014 and April 2015. The interview guide was piloted before the first interview. The interviews dealt with themes such as farming history, motivations for conversion, experiences from the conversion process, farmer identity and future expectations. The interviews were semi-structured as flexible conversations to allow enough scope for the interviewers to be responsive to the issues raised by the pioneer organic farmers (see Legard et al., 2003). Furthermore, we did not use the word 'stigma' during the interviews unless the respondents used it themselves. In this way, we wanted to ensure that potential stigmatization of organic farming was not produced by the interviewers. The interviews were recorded and transcribed.

Our research relied on pioneer organic farmers' memories of the conversion from conventional to organic farming in the late 1970s or 1980s. As a data gathering method, this type of study, based on individuals' memories, has raised some criticism - particularly regarding the validity of retrospective accounts (see Keightley, 2010). While acknowledging the criticism, we emphasize that in our study, we understand memory as a lived process of making sense of time and the experience of it (Keightley, 2010, p.56). Memory is not simply about an accurate record of the past but an effort after meaning (Bartlett, 1932). Accordingly, in our study, the pioneer organic farmers, by memorizing the early organic farming careers, were making sense and giving meaning to what happened to them during their early organic farming careers.

Our data analysis was inductive and based on detailed readings of raw data to derive concepts, themes and a model through interpretations made from the raw data by the researchers (e.g. Patton, 2002; Thomas, 2006). We started the data analysis by reading through the transcribed interviews several times during which we started to categorize and code the empirical material. During this phase, we were able to establish that the pioneer organic farmers considered having stigmatized identities when starting their organic farming careers. Accordingly, the interviewees thought that contemporary farmers regarded them with negative attributes, like being a 'village idiot' or an 'oddity' in the farming community. Organic farmers were not considered as 'real farmers' but instead, as 'overtly green world saviours who just potter about farming'. While organic farmers arouse scepticism in their local farming communities, the farmers felt that the conversion to organic farming marginalized themselves in the local farmer community, as one of the pioneer farmers stated: "Well, my neighbours didn't consider me as a farmer at all. They didn't agree to talk with me. And I guess local farmers were trying to avoid me". This kind of marginalization is associated with stigmatization.

After this phase, we reviewed the coded text to gain a more profound understanding of the empirical material and to identify the different stigma management strategies the pioneer organic farmers used, by focusing on how they dealt with their identities as stigmatized farmers (see Toyoki and Brown, 2014). We paid particular attention to the ways in which the pioneer organic farmers characterized, directly or indirectly, their relationship with other farmers (see Lutgen-Sandvik, 2008). This phase of the analysis resulted in open codes for identity work in the pioneer organic farmers' narratives. We then examined the coded text instances, and based on their semantic contents, we grouped the codes under larger, more descriptive identity work themes, which were termed neutralization and connecting to socially valued identity blocks. The analysis process was a continuous iteration (e.g. Wodak, 2001) between the data and the theoretical framework to understand how these themes were associated with the previous literature. In order to evaluate and enhance the credibility of the study, the results were further presented and discussed with a group of three people consisting of organic farming advisors who had already started their careers in the 1980s. These experienced experts supported the interpretations made in the study.

\section{Empirical results - discursive stigma management strategies of pioneer organic farmers}

\subsection{Neutralization by contesting the legitimacy of conventional farming}

From the perspective of Finnish agriculture, the timeframe examined in this study can be characterized as striving for advanced rationalization, mechanization and strong increase in productivity, strengthened by the national agricultural policy (e.g. Jokinen, 2000). In the farming community, the act of not utilising chemical fertilizers and pesticides, positioned the pioneer organic farmers as fighting against the ideas of modern, efficient agriculture. For example, one pioneer organic farmer stated that "Surely you became an oddity in a village if you leave all the fertilizers and poisons - it was just weird at the time" (Int 2). However, after acknowledging the existence the stigma, he challenged it by highlighting the potential health risks associated with the usage of pesticides and herbicides: "But I thought that using all kind of poisons that would surely be a risk considering that all kind of diseases are increasing".

The pioneer organic farmers tried to neutralize the stigma by questioning the legitimacy of conventional farmers as stigma communicators (see Sykes and Matza, 1957). This discrediting effort was grounded on the very same characteristics that were used to stigmatize

Table 2

The methods the pioneer organic farmers used to contribute in the institutional agricultural change.

\begin{tabular}{ll}
\hline Ways to contribute to the agricultural change & Mentioned by (number of interviewees) \\
\hline Taking actively part in organic farming associations (both at regional and national level) & all interviewees \\
Influence through media (Letters to the Editor, articles, television/radio presentations) & $2,4,5,7,10,11,12,13,14$ \\
Establishing associations, study groups and courses & $3,4,11,13$ \\
Lobbying (agricultural union, universities) & $1,3,8,11,12,13,14$ \\
Political action & 3,14 \\
\hline
\end{tabular}


organic farmers in the first place, namely the non-usage of chemical fertilizers and pesticides. Accordingly, in their interview narratives the pioneer organic farmers aimed to demonstrate the ill-effects of conventional farming and simultaneously positioned themselves as conscious farmers, who made the sensible decision to give up the "chemicalization' in order to preserve their own health as well as the health of consumers and the soil (see also Lockeretz and Madden, 1987; Stock, 2007). The following interview citations illustrate the farmers positioning:

\begin{abstract}
"Organic farming was very strange at the time and I got a reputation of being some kind of village idiot. But I farmed conventionally for few years and also used pesticides and herbicides. In those days, pest controlling was done without any protective equipment and in a windy day, my hands and face was covered with pesticides. In that point, I started to question that behaviour, I didn't want to lose my own health while farming. For me it's important that the products are healthy for humans and that is a self-evident thing in organic farming because there is no spraying of poisons". (Int 1)
\end{abstract}

"I guess the real farmers were laughing at me when I started organic farming. But for me becoming an organic farmer meant that the welfare of the soil improved a lot. When I was farming conventionally I personally noticed the impoverishment of the soil. I knew that I couldn't continue farming like that ... After converting to organic farming, the quality of the soil improved and there were worms at the soil again. And the crops were also fair, so I didn't have anything to be ashamed of". (Int 6)

The idea of organic farming as an unmodern farming method was usually also considered to signify poor economic prospects for farmers a view that was further used to stigmatize the pioneers of organic farming. For example, one pioneer farmer recalled that the decision he and his wife made when converting to organic agriculture was considered particularly odd among the nearby farmers as it was thought to lead to economic ruin of the farm. Similarly, another interviewed farmer described how the neighbouring farmers perceived organic farming as economically unreasonable and unsustainable. She remembered that "the neighbouring farmers were asking my father that 'How long do you have money to support your daughter's organic farming?" (Int 8). Since economic arguments were frequently highlighted when organic agriculture was negatively labelled, the pioneer organic farmers also used economic rationalities to deflect the attention from their own farming to the ostensible shortcomings of conventional farming. They emphasized the idea of self-sufficiency as an important reason for their interest in organic farming methods and questioned the economic rationality and benefits of conventional farmers' dependency on synthetic, non-renewable fertilizers.

"For me it was a relief to start farming organically. I didn't have to pay expensive pesticides or chemical fertilizers anymore. It's a huge annual investment you have to make when paying the chemical fertilizers, especially when you think that nitrogen can be freely available when you utilize the organic principles in your farming. You just don't have to pay for the chemical industry for that". (Int. 5)

Because of the avoidance of modern chemical fertilizers and pesticides, organic farming was frequently claimed to result in lower quality yields and organic farmers were stigmatized as "weed growers". The lower yields were not, however, used only to stigmatize the individual farmers, but also the farming method in more general. Accordingly, organic farming was considered to lead to a lower (national) food supply - hence making the country more vulnerable and dependent on imported foods. In order to confront this stigmatizing judgement, the pioneer organic farmers utilized the national-level agricultural discourses. In the 1980s, a significant drawback of intensifying agriculture in Finland was overproduction that raised a lot of political discussion (e.g. Kettunen, 1984). Accordingly, highlighting the problems of overproduction was a means for the pioneer organic farmers to question the legitimacy of conventional farming, like the following interview citation illustrates:

"I always said that if we have to limit the amount of our agricultural production because of the overproduction, why on earth do we use imported resources to enable the overproduction, while we could adopt a farming method in which we don't need any imported input, but rather every farm can produce its own fertilizers, where the yield levels decrease and we don't have to struggle with overproduction". (Int 3)

In summary, by shifting the focus of attention from the deviant behaviour of organic farmers to questioning the reasonability of conventional farming, the pioneer organic farmers not only challenged conventional farmers as stigma communicators, but implicitly produced their own farming practice as economically and morally valuable.

\subsection{Neutralization by transferring the stigma to biodynamic farming}

The founder of biodynamic farming, Rudolf Steiner, aimed at demonstrating that by cutting out the use of chemical fertilizers and pesticides and by suggesting how cosmic forces could be used to control biological processes, a new direction for agricultural processes could be shown (Kirchman, 1994). Biodynamics involved ideological underpinnings to agriculture that were not inherent in conventional farming. For example, biodynamic farming suggests that planets radiate forces that influence plants and animals and should therefore be taken into consideration in farming decisions (Kirchman, 1994, p.177). The idea of cosmic forces being a part of farming was used as a mystifying attribute of organic production - thus resulting to a stigma in organic farming methods. In the words of one pioneer organic farming: "Other farmers considered it some kind of witchcraft because I tested these biodynamic ideas". (Int 11)

One strategy the pioneer organic farmers used to neutralize the stigma of organic farming was to deny its applicability to their farming by transferring the stigmatized attributes to biodynamics. According to Meisenbach (2010), individuals often select a group that is similar to them so that the connection is meaningful while discursively making clear that this other group is culturally and socially more prone to stigmatization. The pioneer organic farmers aimed to dissociate themselves from biodynamic farmers by distancing themselves from the doctrines of biodynamics. In line with Snow and Anderson (1987, p. 1349) it can be stated that since the pioneer organic farmers' claim to a particular self was partly contingent on the imputed social identities of their associates (biodynamic farmers) by way of chemical free farming, one way to substantiate that claim, in the event that biodynamic farmers were negatively evaluated, was to distance oneself from them. In addition to the farming community, this distancing was also aimed at convincing the more general public of the difference between biodynamic and organic farming:

"I did familiarize with the principles of biodynamic farming and noticed rather quickly that it's mostly based on beliefs. It has been a large effort to explain the farming community, and also the scientists, that we are not ... we present the pure scientific approach to farming. For those farmers endowed with common sense, biodynamic farming is farming based on suppositions and beliefs". (Int 12)

The pioneer organic farmers often highlighted their rational nature when producing the discursive distance between themselves and biodynamic farmers. For example, in the following interview citation the pioneer organic farmer was asked whether she ever considered applying biodynamic farming methods when starting organic agriculture. While dissociating herself from biodynamic farmers, the interviewee aimed to produce herself as a rationally-oriented farmer with common sense, thus transferring the irrational and mystic stigmatizing attributes to biodynamic farmers: 
"I'm too rational a person for biodynamic farming, it would never suit me. I have never figured out the power of stars and moon and all that. I have sometimes looked at the cultivation calendar just out of sheer curiosity, but I have never made any biodynamic preparations. It has never been my thing and that was very clear for me from the very beginning, even though I know biodynamic principles quite well". (Int. 4)

The following interview citation further exemplifies the transfer of stigmatizing attributes to biodynamic farming. The interviewed farmer started his farming career by applying biodynamic practices but soon found out that the extra work involved in biodynamics increased ineffectiveness in his work. By highlighting the labour-intensive aspects of biodynamics, he simultaneously produces these aspects as being uneconomic. His narrative labels biodynamic farming as irrational in the economic sense, and strengthens the categorical distinction between these two farming methods.

"Biodynamic farming includes preparations and all kind of extra work. I came to the conclusion that there is no practical benefit from this extra work and abandoned the preparations and cultivation calendars. It was an extra cost, labour cost and I think it is important to calculate whether or not something produces any benefits. For me, farming should also be mathematics." (Int. 11)

Due to giving up modern chemical applications, organic farming was often considered as a return to outdated farming practices that would require a lot of human effort. Accordingly, organic farming was labelled as being small-scale, something different from "real [conventional] farming". In order to avoid the image of being a less-professional farmer, the pioneer organic farmers further transferred the hobby-like impression of farming to biodynamic farmers. As one of the interviewees stated "the biodynamic farming methods are impossible to apply on any larger scale [...] But it can be applied on small farms, and I don't say this in any negative sense, but there are these smaller farms, and a good example is that someone buys a farm and starts small-scale farming with ideological guidelines" (Int 3).

As the examples above demonstrate, the pioneer organic farmers did not recognize the stigmatizing attributes as being characteristics of their own farmer identities. Instead, they positioned themselves outside the stigmatized group and separated their identities from those of biodynamic farmers. The neutralization thus evoked space for the alternative identity narratives.

\subsection{Connecting to socially valued identity blocks}

As an important part of their stigma management processes, the pioneer organic farmers connected to culturally coveted social identities (see Toyoki and Brown, 2014). Hence, instead of accepting the deviance imbued in their farmer identities, the pioneer organic farmers characterized themselves through the membership of socially valued categories like an entrepreneur and innovator. The entrepreneurial identity was often produced by sharing stories which highlighted the success of organic farmers and farms - described through conventionally accepted qualities, like the farm size and yield levels, like the following interview citation demonstrates:

"We knew what farming was like in the 1930s and 1940s. None of use wanted to return to that. [...] I have always been eager to make calculations, and when I started organic farming I did calculate that it is economically a more rational option for me than conventional farming. It was a profitable and wise business decision. And we have had quite good yield levels and they have actually increased all the time". (Int 7)

The pioneer organic farmers further built their entrepreneurial identities by highlighting that organic farming provided them an innovative space to diversify their distribution channels and the clientele. More specifically, in the pioneer organic farmers' narratives, early organic farming was often linked in their indefatigable effort to find consumers for their produce. While consumers that appreciate organic products were not necessarily located in the neighbourhood, but more likely in the larger cities, marketing was often challenging and required a lot of time, new ideas, and money. By stressing their own role and responsibility for responding to the economic challenges in their farming, the pioneer organic farmers distinguished themselves, to some extent, from the contemporary producer-farmer identity that emphasized relying on state interventions, governmental protection and subsidies (Pyysiäinen, 2011). For example, in the following interview citation, the pioneer organic farmer states that for him, the willingness to demonstrate to sceptics that organic farming can be an economically profitable way of farming, was an important driving force in his farming career. He managed to turn his farm into a successful business by diversifying the farm activities and showing an entrepreneurial spirit:

"When I started organic farming, one of the most prevailing prejudices was that organic farming can be a successful farming practice in small gardens, but not on a large, proper farm. And this was the main challenge for me, I wanted to prove that organic farming works well for large scale farming too. [...] Organic farming gave us an opportunity to further process our products and we established a farm bakery. We sold bread to consumers and in that way organic farming gave us totally new possibilities. Soon we had regular customers which made it easier us to further develop the farm". (Int 1)

Searching, developing and trying new products, markets and methods is often linked with innovativeness (see Vesala et al., 2007) an attribute that was frequently referred to in the pioneer organic farmers' identity narratives. Accordingly, the pioneer organic farmers positioned themselves as innovators who took the challenge to create something new and highlighted their own important role in developing the methods and principles of organic farming. In these narratives, the pioneer organic farmers presented themselves as hard-working, dedicated and resourceful. The narratives emphasized the fact that when the pioneer organic farmers started their organic farming careers, the institutionalized agriculture did not provide very much assistance:

"I'm not saying that conventional farming was easy since there are all kinds of challenges in conventional farming too, but still I think that organic farming was really much more demanding. When I started organic farming, there wasn't any advice. We had to figure everything out by ourselves. I guess we have learnt everything by trial and error". (Int 4)

Being an innovator is often associated with a certain independence and ignorance of social pressures. Accordingly, the pioneer organic farmers emphasized persistence as an important feature of their characters. For example, one of the pioneer organic farmers took a very active role in the media as he argued for the organic change in contemporary farming. He highlighted persistence in getting his message through in the media:

"I went to see the editor-in-chief of Maaseudun Tulevaisuus [nationally circulated newspaper]. I thought that I'll just show him that I'm not crazy even though I'm an organic farmer and I have a beard. That I have quite a normal logic. And because of my visit, he agreed to publish my article. But if I just had sent it in the mail, they would have never published it". (Int 14)

Indeed, perseverance, referring to the capability to take repeated or different actions to overcome obstacles, is often considered as a vital element for successful entrepreneurs (McClelland, 1987). In the following interview citation, the farmer was asked as to what kind of reactions his conversion to organic agriculture aroused in the local community. Even though the pioneer organic farmer remembers scepticism and laughter, he still emphasizes his ignorance of stigmatizing reactions. Thus, instead of being willing to hide his ambiguity towards changing the contemporary farming culture, the stigmatization made him even more determined in his endeavour. 
"There was always laughing. People made jokes and were mocking us and things like that, but it never depressed me. It was not like that, nothing would have resulted in me quitting organic farming. On the contrary, it merely gave me more of a boost". (Int 2)

Indeed, institutional entrepreneurs are thought to share autonomous reflexivity, which is characterized by internal dialogue, which does not need to be supplemented with other people (Mutch, 2007). Accordingly, the ability towards internal reflexivity enables institutional entrepreneurs to pursue their own projects even though they might be in conflict with existing structures, like the following interview citation demonstrates:

"I have never got any crown for being an organic farmer but somehow the feeling that I have been doing the right thing, that my conscience says that I have been doing the right thing, is important and enough for me. It was a meaningful role to work as kind of pioneer. I have really liked that role". (Int 7)

It is still important to notice that, despite the emphasis on independence and autonomy associated with the pioneer organic farmers' entrepreneurial self-narratives, they also strongly emphasized the important role of social networks with like-minded organic farmers when developing new ideas and practices. Stigmatization of organic farmers meant that there was often very little dialogue between organic and conventional farmers because they were relying on different information sources (Rigby et al., 2001). In order to redefine their place in society, the pioneer organic farmers actively extended their social networks beyond the spatial borders of their local community, like the following interview citation shows:

"The social networks with other organic farmers were really important for me. You have more courage when you are part of a group". (Int 11)

This in-group identification was often expanded to pioneer farmers in other European countries. Thus, other European countries - and particularly Sweden, Denmark and Germany - were often represented as model countries that were used as standards measuring whether organic issues could pay off. The social connections that the pioneer organic farmers had with their colleagues in these countries were emphasized in order to strengthen their status as international actors. Consequently, by expanding the context used for comparisons, the pioneer organic farmers presented themselves as informed with global agricultural development.

\section{Discussion - the model of stigma management in institutional entrepreneurship}

The empirical results show the pioneer organic farmers' identity management process whereby they rejected their stigmatized identities and transformed them into something that is valued and desirable. This process of identity disclosure consisted of two strategies which we named as neutralization and connecting to socially valued identity blocks. In this section, we further discuss how the stigma management process contributed to the pioneer organic farmers' institutional entrepreneurship (see Fig. 1). We suggest that stigma management aiming at a socially accepted organic farmer identity was a significant antecedent that enabled the pioneer organic farmers' engagement in the agricultural institutional work. The previous research has shown that it is through accepted identities that the associated new logics can become institutionalized (e.g. Lounsbury, 2001; Rao et al., 2003). For this reason, identity (re)construction from a negatively labelled 'village idiot' and 'oddity' to an innovative, entrepreneurial and resourceful farmer appears central to the attempts to frame the need for institutional change (see Greenwood et al., 2002).

In the pioneer organic farmers' stigma management process, neutralization singled out the stigmatizing attributes by contesting the legitimacy of stigma communicators (mainly conventional farmers) and transferring the stigmatizing features to other actors (mainly biodynamic farmers). Our empirical study shows that even though the pioneer organic farmers acknowledged their deviant identities among contemporary conventional farmers, they were not accepting the culturally set conception of "normal farmer" which referred to the conventional farmer. Neutralization, thus, aimed to normalize organic farmers and their farming decisions by a cleansing of the 'tainted self' (e.g. Warren, 1980). The process of connecting to socially valued identity blocks, on the other hand, aimed to portray organic farmers as a specific social group by emphasizing their self-value. As previous research has shown, stigmatized "individuals can strategically emphasize identities that are valued and de-emphasize identities that are not in any given social context" (Shih, 2004, p. 180). Accordingly, through connecting to socially valued identity blocks, pioneer organic farmers aimed to redefine their place in society by strengthening their sense of belonging to a valued and legitimate in-group, namely those of entrepreneurs and innovator s (see Kreiner et al., 2006).

Stigmatization creates inequality, undermines trust and reduces opportunities for interpersonal interactions between stigmatized group and stigmatizers (e.g. Link and Phelan, 2006). Thus, it can be argued that stigma may create barriers against social capital construction. Accordingly, the previous stigma management literature has suggested that stigmatized people often isolate themselves from society through socializing only with other stigmatized individuals (e.g. Goffman, 1963; Meisenbach, 2010). For the pioneer organic farmers, social bonds with other organic farmers were not, however, a means to social isolation. On the contrary, the active stigma management by the pioneer organic farmers enabled them to construct social capital as they connected with other like-minded farmers with bonds that were based on shared experiences (see Putnam, 1995; Portes and Landolt, 2000). Thus, bonding with other organic farmers was considered as a way to gain important valuable information and skills that helped farmers to develop organic farming methods, and furthermore, an important resource in their endeavours to change the agricultural status quo.

Still, it is equally important that stigma management enabled the pioneer organic farmers to start reconstructing social capital between themselves and conventional farmers as successful institutional entrepreneurship requires the ability to influence multiple actors and their actions (Fligstein, 1997). Therefore, while questioning the legitimacy of conventional farmers as stigma communicators, the pioneer organic farmers still used the conventional, productivist (Burton, 2004) discourse to demonstrate how the stigmatizing attributes of organic farming can be a means leading to valuable ends and as a result identifying the stigmatizing attributes with higher purposes. Thus, even though highlighting the economic and environmental weaknesses of conventional agriculture was an attempt to shift normative consensus away from intolerance of organic farming, the pioneer organic farmers were simultaneously building normative legitimacy for organic farming by seeking the certain congruence with conventional farming in the larger social system and in the farming community. For example, the pioneer organic farmers constructed organic farming as a lucrative choice by using productivist expressions (high yields, quality livestock, tidy fields) instead of talking about small-scale, ideologically driven farming. By utilising the productivist discourse in their stigma management, the pioneer organic farmers aimed to create trust between themselves and conventional farmers and frame the agricultural innovation so that it might also be broadly accepted among existing agricultural actors (see Rao, 1994). We suggest that drawing on the conventional agricultural discourse in their stigma management was significant in enabling the social capital building between pioneer organic farmers and conventional farmers (see Michelsen et al., 2001). Hence, the stigma management strategies that the pioneer organic farmers adopted, contributed to the development of organic agricultural institutions in continuous contact with conventional agriculture.

Although seeking legitimacy among conventional farmers was an 


\section{SOCIAL DEVALUATION} BY DOMINANT ACTORS

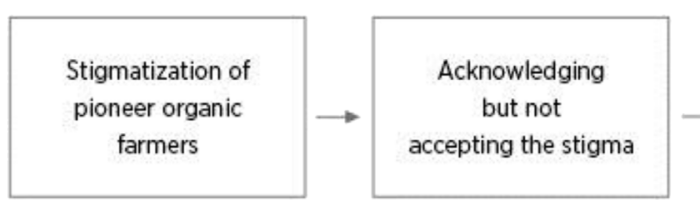

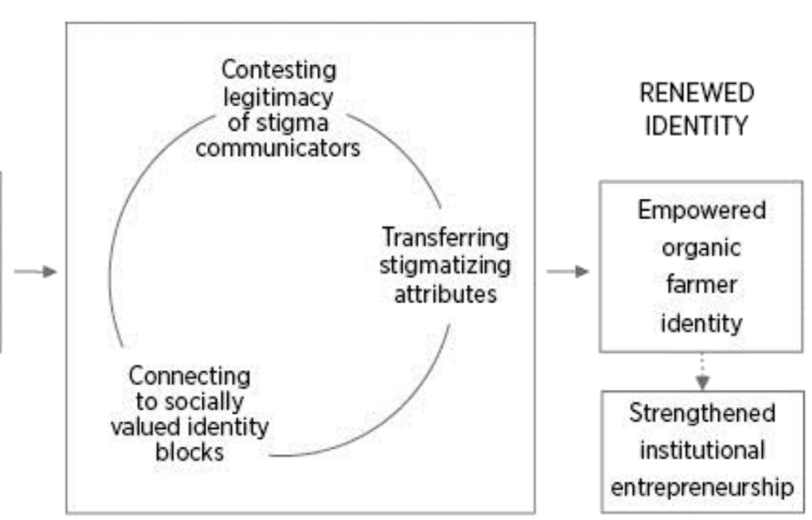

Fig. 1. Pioneer organic farmers' stigma management process.

essential element in their stigma management, it should also be noticed that from the very beginning, the pioneer organic farmers were actively building a new agricultural category which was different from that of conventional farming. We argue that the active and explicit aim for category building protected their self-worth in the process of stigmatization. Through the stigma management process, the pioneer organic farmers (re)produced their self-identities and defined what it means to be an organic famer. Even though they acknowledged the contemporary stigmatizing attributes, they did not internalize or accept them as part of their self-identities. Instead, they actively managed stigma to reverse deviance to uniqueness. Thus, instead of being oppressed by stigmatization, the pioneer organic farmers were empowered by it. The idea of stigma management as an empowering process proposes that overcoming the social hardships related to their conversion to organic farming was an enriching process through which the pioneer organic farmers developed a sense of mastery and self-efficacy at their accomplishments (see Shih, 2004).

\section{Conclusions}

Our study contributes to the discussion of organic farming by demonstrating how the pioneer organic farmers overcame the negative attributes associated with their farmer identities. Characteristics for their stigma management process was that they did not produce themselves as passive targets of prejudice who focused on evading negative outcomes of stigmatization, neither did the difficulties they experienced in their early organic careers translate into negative emotional reactions. Instead, the pioneer organic farmers perceived stigma management as an empowering process, which according to our suggestion, enabled their mission to contribute to the change of prevailing agricultural norms.

Our study has certain limitations that indicate the need for further research. Our research data was gathered solely in the Finnish organic farming context. Even though we suggest that the results of this study can increase understanding of the challenges in mainstreaming social and environmental innovations in general, the results need to be tested in other contexts. We also acknowledge that our research focused on those pioneer organic farmers who were able to successfully manage the contemporary stigmatization which has naturally affected their meaning making processes. By taking a different focus, for example by including those farmers who were not able to cope with stigmatization but either returned back to conventional farming methods or ended their farming, would have produced a different interpretation of the stigma management of pioneer organic farmers. However, the focus we adopted in this study enabled us to examine the stigma management from the viewpoint of those organic farmers who participated in the institutional change in the Finnish agriculture. Therefore, including the voices and stigma management strategies of those farmers who were not able to cope with the stigma would be an interesting future contribution to stigma management discussion in the context of organic farming.

Achieving the goal of a sustainable economy not only requires implementing innovative and appropriate solutions, but also societal acceptance towards these goals. Sustainable innovations and business models often challenge the institutionalized status quo. As the results of our research show, such innovations may encounter opposition among the mainstream actors, resulting in counter strategies such as negative labelling and stigmatization. Stigmatization further hinders the development of the industry resulting in minimal resources allocated for its development. Even though our focus in this study was on organic farming, we suggest that many social and environmental innovations, while challenging the institutionalized conventional practices, face similar kinds of stigmatization as organic farming once did - and still does in some contexts. Thus, our stigma management model has applicability beyond the organic farming context as it depicts more generally how marginalized social actors can contest negative labelling and enable the transformation towards more sustainable society.

\section{Acknowlegdements}

The research has been funded by Academy of Finland (grant numbers: 296726, 260138).

\section{Appendix A. Supplementary data}

Supplementary data to this article can be found online at https:// doi.org/10.1016/j.jrurstud.2018.10.008.

\section{References}

Alvesson, M., Ashcraft, K.L., Thomas, R., 2008. Identity matters: reflections on the construction of identity scholarship in organization studies. Organization 15 (1), 5-28. Ashforth, B.E., Kreiner, G.E., 1999. "How can you do it?" Dirty work and the challenge of constructing a positive identity. Acad. Manag. Rev. 24 (3), 413-434.

Asforth, B.E., Kreiner, G.E., 2014. Dirty work and dirtier work: differences in countering physical, social, and moral stigma. Manag. Organ. Rev. 10 (1), 81-108.

Ashforth, B., Kreiner, G., Clark, M., Fugate, M., 2007. Normalizing dirty work: occupational tactics for countering occupational taint. Acad. Manag. J. 50 (1), 149-174.

Bartlett, F.C., 1932. Remembering: a Study in Experimental and Social Psychology. University Press, Cambridge.

Battilana, J., Leca, B., Boxenbaum, E., 2009. How actors change institutions: towards a theory of institutional entrepreneurship. Academy of Management Annals January 3 (1), 65-107.

Burton, R.J.F., 2004. Seeing through the 'good framer's' eyes. Towards developing an understanding of the social symbolic value of 'productivist' behaviour. Sociol. Rural. 44 (2), 195-215.

Crocker, J., Major, B., 1989. Social stigma and self-esteem: the self-protective properties 
of stigma. Psychol. Rev. 96, 608-630.

Crocker, J., Major, B., Steele, C., 1998. Social stigma. In: Gilbert, D., Fiske, S.T., Lindzey, G. (Eds.), The Handbook of Social Psychology, fourth ed. vol. 2. McGraw Hill, New York, pp. 504-553.

Crowder, D.W., Reganold, J.P., 2015. Financial competitiveness of organic agriculture on a global scale. Proc. Natl. Acad. Sci. U. S. A. 112, 7611-7616.

Duram, L., 2010. Encyclopedia of Organic, Sustainable, and Local Food (Santa Barbara: ABC-CLIO).

EU, 2015. Fact and figures on organic agriculture in the European Union. https://ec europa.eu/agriculture/organic/eu-policy/data-statistics_en, Accessed date: 6 September 2018.

Evira, 2016. Organic production in a nutshell. https://www.evira.fi/en/shared-topics/ organic-production/, Accessed date: 1 March 2017.

Evira, 2017. Organic farms and the share of organic farming in Finland. https://www evira.fi/globalassets/yhteiset/luomu/tilastot/luomu-2017ep2.pdf, Accessed date: 6 September 2018.

Falk, G., 2001. Stigma: How We Treat Outsiders. Prometheus Books, New York, USA.

Fligstein, N., 1997. Social skill and institutional theory. Am. Behav. Sci. 40 (4), 397-405.

Garud, R., Hardy, C., Maguire, S., 2007. Institutional entrepreneurship as embedded agency: an introduction to the special issue. Organ. Stud. 27 (7), 957-969.

Glezos, L., 2016. The Emergence of Organic Food Market in Australia: an Economic Sociological Approach. Dissertation. Swinburne University of technology, Faculty of Business and Law.

Goewie, E.A., 2002. Organic agriculture in The Netherlands; developments and challenges. Neth. J. Agric. Sci. 50 (2), 153-169.

Goffman, E., 1963. Stigma: Notes on the Management of Spoiled Identity. Prentice Hall, Upper Saddle River, NJ.

Greenwood, R., Suddaby, R., Hinings, C.R., 2002. Theorizing change: the role of professional associations in the transformation of institutionalized fields. Acad. Manag. J. 45 (1), 58-80.

Herman, A., Lähdesmäki, M., Siltaoja, M., 2018. Placing resilience in context: in vestigating the changing experiences of Finnish organic farmers. J. Rural Stud. 58, $112-122$.

Hudson, B.A., 2008. Against all odds. A consideration of core-stigmatized organizations. Acad. Manag. Rev. 33 (1), 252-266.

Ingram, J., 2015. Framing niche-regime linkage as adaptation: an analysis of learning and innovation networks for sustainable agriculture across Europe. J. Rural Stud. 40, $59-75$.

Jokinen, P., 2000. Europeanisation and ecological modernization: agri-environmental policy and practices in Finland. Environ. Polit. 9 (1), 138-167.

Kaltoft, P., 1999. Values about nature in organic farming practice and knowledge. Sociol. Rural. 39 (1), 39-53.

Keightley, E., 2010. Remembering research: memory and methodology in the social sciences. Int. J. Soc. Res. Methodol. 13 (1), 55-70.

Kettunen, L., 1984. Suomen Maatalous Vuonna 1983 [Finnish Agriculture in 1983]. The Agricultural Economics Research Institute, Helsinki, Finland.

Kirchman, H., 1994. Biological dynamic farming - an occult form of alternative agriculture? J. Agric. Environ. Ethics 7 (2), 173-187.

Kreiner, G.E., Ashforth, B.E., Sluss, D.M., 2006. Identity dynamics in occupational dirty work: integrating social identity and system justification perspectives. Organ. Sci. 17 (5), 619-636.

Källander, I., 2007. Ecological farmers association and the success of Swedish organic agriculture. In: Lockeretz, W. (Ed.), Organic Farming: an International History. CABI, Wallingford, pp. 201-216.

Lawrence, T.B., Hardy, C., Phillips, N., 2002. Institutional effects of interorganizational collaboration: the emergence of proto-institutions. Acad. Manag. J. 45, 281-290.

Leca, B., Battilana, J., Boxenbaum, E., 2008. Agency and Institutions: a Review of Institutional Entrepreneurship. Working paper.

Legard, R., Keegan, J., Ward, K., 2003. In-depth interviews. In: Ritchie, J., Lewis, J. (Eds.), Qualitative Research Practice. A Guide for Social Science Students and Researchers. Sage, Thousand Oaks, pp. 138-169.

Link, B.G., Phelan, J., 2001. Stigma power. Soc. Sci. Med. 103, 24-32.

Link, B.G., Phelan, J.C., 2006. Stigma and its public health implications. Lancet 367, 528-529.

Lockeretz, W., 2007. What explains the rise of organic farming? In: Lockeretz, W. (Ed.), Organic Farming. An International History. CABI, Cambridge, pp. 1-8.

Lockeretz, W., Madden, P., 1987. Midwestern organic farming: a ten-year follow-up. Am. J. Altern. Agric. 2 (2), 57-63.

Lounsbury, M., 2001. Institutional sources of practice variation: staffing college and university recycling programs. Adm. Sci. Q. 46 (1), 29-56.

Luomuliitto, 2005. Finnish organic association. http://www.luomuliitto.fi/tekstit/ luomuliitto_20_vuotta.pdf, Accessed date: 14 September 2016.

Lutgen-Sandvik, P., 2008. Intensive remedial identity work: responses to workplace bullying trauma and stigmatization. Organization 15 (1), 97-119.

Maguire, S., Hardy, C., Lawrence, T.B., 2004. Institutional entrepreneurship in emerging fields: HIV/AIDS treatment advocacy in Canada. Acad. Manag. J. 47 (5), 657-679.

Major, B., O_Brien, L.T., 2005. The social psychology of stigma. Annu. Rev. Psychol. 56, 393-421.

McClelland, D.C., 1987. Characteristics of successful entrepreneurs. J. Creativ. Behav. 21 (3), 219-233.

McGreevy, S.R., 2012. Lost in translation: incomer organic farmers, local knowledge, and the revitalization of upland Japanese hamlets. Agric. Hum. Val. 29 (3), 393-412.

Meisenbach, R.J., 2010. Stigma management communication: a theory and agenda for applied research on how individuals manage moments of stigmatized identity. J. Appl. Commun. Res. 38 (3), 268-292.

Michelsen, J., 2001. Recent development and political acceptance of organic farming in Europe. Sociol. Rural. 41 (1), 3-20.
Michelsen, J., Lynggaard, K., Padel, S., Foster, C., 2001. Organic Farming Development and Agricultural Institutions in Europe: a Study of Six Countries. Organic Farming in Europe: Economic and Policy, vol. 9 University of Hohenheim, Hohenheim.

Miller, C.T., Kaiser, C.R., 2001. A theoretical perspective on coping with stigma. J. Soc. Issues 57, 73-92.

Mononen, Tuija, 2008. Luomun Verkostot - Tutkimus Suomalaisen Luomutuotannon Toimijaverkostojen Muutoksesta. Joensuun Yliopiston Yhteiskuntatieteellisiä Julkaisuja Nro 85. Joensuun yliopisto. http://urn.fi/URN:ISBN:978-952-219-083-3.

Mutch, A., 2007. Reflexivity and the institutional entrepreneur: a historical exploration. Organ. Stud. 28 (7), 1123-1140.

Nguyen, H.P., Chan, S., Mukherjee, A., 2014. Reverse stigma in the Freegan community. J. Bus. Res. 67, 1877-1884.

Organic Europe, 2012. Country report - Finland 2012. https://www.organic-europe.net/ country-info/finland/country-report.html.

Padel, S., 2001. Conversion to organic farming: a typical example of the diffusion of an innovation? Sociol. Rural. 41 (1), 40-61.

Padel, S., Lampkin, N., 2007. The development of governmental support for organic farming in Europe. In: Lockeretz, W. (Ed.), Organic Farming. An International History. CABI, Cambridge, pp. 93-122.

Paetzold, R.L., Dipboye, R.L., Elsbach, K.D., 2008. A new look at stigmatization in and of organizations. Acad. Manag. Rev. 33 (1), 186-193.

Patton, M.Q., 2002. Qualitative Research \& Evaluation Methods, third ed. Sage, Thousand Oaks.

Phelan, J.C., Link, B.G., Dovidio, J.F., 2008. Stigma and prejudice: one animal or two? Soc. Sci. Med. 67, 358-367.

Portes, A., Landolt, P., 2000. Social capital: promise and pitfalls of its role in development. J. Lat. Am. Stud. 32 (2), 529-547.

Putnam, R.D., 1995. Tuning in, tuning out: the strange disappearance of social capital in America. Political Science \& Politics 28 (4), 664-683.

Pyysiäinen, J., 2011. Constructing and Negotiating Entrepreneurial Agency. A Social Psychological Approach to Entrepreneurship Discourse in the Farm Context. Dissertation. University of Helsinki, Department of Social Research, Helsinki, Finland.

Rajala, J., 1995. Luonnonmukainen Maatalous. Helsingin Yliopisto, MaaseuduntutkimusJa Koulutuskeskus, Mikkeli, vol. 38 Julkaisuja, Mikkeli.

Rao, H., 1994. The social construction of reputation: certification contests, legitimation, and the survival of organizations in the American automobile industry 1895-1912. Strat. Manag. J. 15, 29-44.

Rao, H., Monin, P., Durand, R., 2003. Institutional change in Toque Ville: nouvelle cuisine as an identity movement in French gastronomy. Am. J. Sociol. 108 (4), 795-843.

Rigby, D., Woodhouse, P., Young, T., Burton, M., 2001. Constructing a farm level indicator of sustainable agricultural practice. Ecol. Econ. 39 (3), 463-478.

Shih, M., 2004. Positive stigma: examining resilience and empowerment in overcoming stigma. Ann. Am. Acad. Pol. Soc. Sci. 59 (1), 175-185.

Snow, D.A., Anderson, L., 1987. Identity work among the homeless: the verbal construction and avowal of personal identities. Am. J. Sociol. 92 (6), 1336-1371.

Smith, A., 2006. Green niches in sustainable development: the case of organic food in the United Kingdom. Environ. Plann. C Govern. Pol. 24 (3), 439-458.

Stangor, C., Crandall, C.S., 2000. Threat and social construction of stigma. In: Heatherton, T.F., Kleck, R.E., Hebl, M.R., Hull, J.G. (Eds.), The Social Psychology of Stigma. Guilford Press, New York, pp. 62-87.

Stinner, D.H., 2007. The science of organic farming. In: Lockeretz, W. (Ed.), Organic Farming. An International History (Oxfordshire \& Cambridge: CAB Inernational), pp. 40-72.

Stock, P.V., 2007. 'Good farmers' as reflexive producers: an examination of family organic farmers in the US Midwest. Sociol. Rural. 47 (2), 83-102.

Strochlic, R, Sierra, L, 2007. Conventional, Mixed and Deregistered Organic Farmers: Entry Barriers and Reasons for Exiting Organic Production. California Institute for Rural Studies. http://ccwiki.pbworks.com/f/CAStudy-Barriers-Organic-CIRS-2007. pdf.

Sutherland, L.A., 2013. Can organic farmers be "good farmers?" Adding the "taste of necessity" to the conventionalization debate. Agric. Hum. Val. 30 (3), 429-441.

Sveningsson, S., Alvesson, M., 2003. Managing managerial identities: organizational fragmentation, discourse and identity struggle. Hum. Relat. 56 (10), 1163-1193.

Sykes, G.M., Matza, D., 1957. Techniques of neutralization: a theory of delinquency. Am. Sociol. Rev. 22 (6), 664-670.

Thomas, D.R., 2006. A general inductive approach for analyzing qualitative evaluation data. Am. J. Eval. 27 (2), 237-246.

Tovey, H., 1997. Food, environmentalism and rural sociology: on the organic farming movement in Ireland. Sociol. Rural. 37 (1), 21-37.

Tovey, H., 1999. 'Messers, visionaries and organobureaucrats': dilemmas of institutionalisation in the Irish organic farming movement. Ir. J. Sociol. 9 (1), 31-59.

Toyoki, S., Brown, A.D., 2014. Stigma, identity and power: managing stigmatized identities through discourse. Hum. Relat. 67 (6), 715-737.

Van Vuuren, M., Teurlings, J., Bohlmeijer, E.T., 2016. Shared fate and social comparison: identity work in the context of a stigmatized occupation. J. Manag. Organ. 18 (2), 263-280.

Vesala, K.M., Peura, J., McElwee, G., 2007. The split entrepreneurial identity of the farmer. J. Small Bus. Enterprise Dev. 14 (1), 48-63.

Warren, C.A.B., 1980. Destigmatization of identity: from deviant to charismatic. Qual. Sociol. 3 (1), 59-72.

Wheeler, S.A., 2008. What influences agricultural professionals' views towards organic agriculture? Ecol. Econ. 65 (1), 145-154.

Wodak, R., 2001. The discourse-historical approach. In: Wodak, R., Meyer, M. (Eds.), Methods of Critical Discourse Analysis. Sage, London, pp. 63-94.

Yli-Viikari, A., 2016. Kokeilun kipinöistä leviävät murrokset: case luomutuotannon kehitys Suomessa. Alue ja Ympäristö 45 (2), 75-82. 